\title{
Siasat Kompasiana dan Indonesiana dalam Memanfaatkan Raksasa Media Sosial Demi Traffic
}

\author{
Aryo Subarkah Eddyono \\ Program Studi Ilmu Komunikasi Universitas Bakrie Jakarta \\ Email: aryo.subarkah@gmail.com
}

\begin{abstract}
The presence of giant social media (Facebook, Twitter, YouTube, and Instagram) does not necessarily make the mass media afraid and relent without doing anything. The purpose of this study is to answer how are Kompasiana and Indonesiana, media that accommodate content originating from citizens with social media format, in using giant social media? The data were obtained from interviews with the managers of Kompasiana and Indonesiana, observations, documents, and various literatures. The results of this study are, Kompasiana and Indonesiana use giant social media to disseminate content, including promotion or campaign activities; used to increase engagement with members (user account) and the public; used to overcome technological limitations (answering blog video trends); and social media used to discuss issues to determine content policy. The use of the social media giant by Kompasiana and Indonesiana aims at increasing traffic to attract sponsors to advertise. This is important for Kompasiana and Indonesiana to survive and get benefit (capital). This study also shows that in the midst of domination efforts, subordinate groups will always try to get opportunities to survive.
\end{abstract}

Keywords: Social Media, Kompasiana, Indonesiana, Capital, Traffic

Abstrak. Kehadiran raksasa media sosial (Facebook, Twitter, YouTube, dan Instagram) tidak serta merta membuat media massa gentar. Tujuan penelitian ini untuk menjawab bagaimana dengan Kompasiana dan Indonesiana, media yang mengakomodir kontenkonten yang berasal dari warga berformat media sosial, dalam bersiasat memanfaatkan raksasa media sosial? Data-data didapat dari wawancara pengelola Kompasiana dan Indonesiana, pengamatan pada media sosial yang dikelola keduanya, dokumen, serta kepustakaan. Hasil penelitian ini menunjukkan Kompasiana dan Indonesiana memanfaatkan raksasa media sosial untuk untuk menyebarluaskan konten yang dihasilkan, termasuk promosi atau kampanye kegiatan; meningkatkan kedekatan dengan anggota (pemilik akun) dan publik secara umum; dimanfaatkan untuk mengatasi keterbatasan teknologi (menjawab tren video blog); dan media sosial digunakan memantau isu yang tengah tren untuk menentukan arah kebijakan konten. Pemanfaatan raksasa media sosial oleh Kompasiana dan Indonesiana bertujuan pada peningkatan traffic demi mendapatkan sponsor. Ini penting bagi Kompasiana dan Indonesiana untuk bertahan dan mendapatkan keuntungan. Riset ini juga menunjukkan bahwa di tengah upaya dominasi, kelompok subordinat akan terus berusaha mencari peluang agar bisa bertahan.

Kata Kunci: Media Sosial, Kompasiana, Indonesiana, Kepentingan Pasar, Traffic 


\section{Pendahuluan}

Penggunaan internet didominasi oleh aktivitas mengakses media sosial. Hal ini terjadi tidak hanya di Indonesia, melainkan juga di dunia. Dalam kurun waktu dua tahun terakhir, pengguna media sosial terus meningkat. Facebook, YouTube, Twitter, dan Instagram adalah media sosial yang banyak digunakan.

Sepanjang 2017, berdasarkan data yang dirilis We Are Social-Hootsuite (2018), Facebook merupakan media sosial dengan jumlah pengguna terbesar di seluruh dunia, yakni memiliki 2,167 milyar pengguna aktif. Platform media sosial berikutnya adalah YouTube yang memiliki 1,5 miliar pengguna aktif, selanjutnya Instagram dan Tumblr. Lalu, di sepanjang 2018, We Are SocialHootsuite (2019) menunjukkan bahwa Facebook masih berada pada posisi media sosial teratas dengan peningkatan jumlah pengguna aktif mencapai 2,27 milyar. YouTube naik menjadi 1,9 milyar pengguna aktif dari tahun sebelumnya. Twitter memiliki 330 juta pengguna aktif pada 2017, menurun menjadi 326 juta pengguna aktif pada 2018.

Di Indonesia, pada 2017, media sosial yang paling banyak memiliki pengguna adalah YouTube, Facebook, Instagram dan Twitter (Katadata, Januari 2, 2018). Sementara hasil riset We Are Social-Hootsuite (2019) menyebut bahwa pengguna internet di Indonesia telah mencapai 56 persen dari total penduduk Indonesia. Ada peningkatan sebesar 13 persen dari tahun sebelumnya dengan jumlah 17, 3 juta pengguna.

Penetrasi media sosial berdampak bagi penyebaran informasi, termasuk budaya di ruang redaksi (Newman, 2009). Media arus utama seolah tak sanggup mengimbangi kekuatan besar raksasa media sosial itu dalam peredaran informasi. Sehingga, ruang redaksi mau tidak mau bernegosiasi memanfaatkan media sosial - Twitter misalnya - sebagai sumber informasi, memantau topik yang tengah tren untuk membantu menentukan arah pemberitaan, hingga penyebarluasan konten berita sekaligus wahana promosi (Eddyono, 2013). Cara-cara itu dilakukan agar tidak ketinggalan tren, di mana pengguna internet yang terus tumbuh dan tak lagi mendapatkan informasi hanya dari media massa. Menariknya, media sosial dianggap seolah-olah telah menjadi candu baru bagi masyarakat saat ini, seperti halnya agama menjadi candu bagi masyarakat menurut pandangan Marx (Smith, April 4, 2018).

Sejumlah media bahkan menyiapkan secara khusus kanal yang mengangkat topik-topik yang tengah viral di media sosial. Kanal adalah pengelompokkan berita berdasarkan isu atau topik yang sejenis. Tak hanya itu, istilah jurnalisme cek data (fact-checking journalism) belakangan muncul karena ada peluang traffic dari koreksi informasi hoaks yang bertebaran terutama berasal dari media sosial (lihat Nurlatifah dan Irwansyah, 2019). Media-media ini seolah takut tidak kebagian "kue" traffic sehingga beramai-ramai "menambang" informasi di media sosial lalu dijadikan berita. Pada kenyataannya, di sejumlah topik yang diambil dari media sosial lalu dikembangkan atau diangkat di media arus utama berbasis online atau dalam jaringan (daring), mampu meningkatkan traffic bahkan dalam topik-topik tertentu mampu mengalahkan traffic berita-berita dari hasil reportase jurnalis di lapangan. Sehingga apa yang tengah ramai dibicarakan di media sosial, jika pintar menangkap dan mengolahnya kembali, berpotensi mendulang traffic.

Traffic adalah istilah yang digunakan dalam budaya daring untuk 
menggambarkan sejauh mana produktifitas sebuah konten dalam menambah jumlah pembaca, termasuk interaksinya. Traffic ini bermuara pada iklan. Semakin tinggi traffic yang dihasilkan oleh sebuah konten (lalu diakumulasikan dengan traffic yang dihasilkan konten-konten lainnya), maka peluang mendapatkan iklan akan lebih besar. Traffic adalah komoditas, seperti oplah pada koran, pendengar pada radio, ataupun penonton pada TV (Margianto dan Syaefullah, 2012)

Menariknya, berdasarkan diskusi dengan beberapa pengelola kanal di media daring, keberlangsungan sebuah kanal saat ini tergantung seberapa tinggi traffic yang dihasilkannya. Jika tak mampu memenuhi target, maka pendisiplinan oleh manajemen akan terjadi. Kanal-kanal yang tak bisa mencapai target traffic berpotensi ditutup atau disiasati agar bisa memenuhi target traffic yang diharapkan.

Kompasiana dan Indonesiana adalah pada dasarnya merupakan blog yang termasuk dalam kategori media sosial. Keduanya menggunakan model User Generated Content (UGC) yang berarti konten dihasilkan oleh user atau pengguna yang sebelumnya telah teregistrasi. Jadi, baik Facebook, Twitter, YouTube, Instagram, serta keduanya (Kompasiana dan Indonesiana) berada dalam satu jenis, yakni media sosial. Hanya saja, dua nama terakhir tidak sebesar empat nama pertama yang berskala global. Perlu dipahami, blog adalah bagian dari media sosial di mana penggunanya bisa saling berinteraksi, berbagi informasi baik secara individual maupun berkolaborasi dalam skala tertentu, dan sekaligus menyampaikan komentar balik atas isu-isu tertentu. Bradley (2010) menyebut enam prinsip media sosial, yakni: participation; collective; transparency; independence; persistence; dan emergence. Blog memenuhi unsur-unsur tersebut.

Baik pengelola Kompasiana maupun Indonesiana menyadari betapa berat jika ingin melawan ataupun mengimbangi dominasi jumlah konten dan jumlah pengguna media sosial raksasa, terlebih lagi apalagi jika berbicara soal keuntungan dan teknologi (wawancara dengan pengelola, 2017 dan 2018).

Pertanyaannya adalah bagaimana blog seperti Kompasiana dan Indonesiana bersiasat menghadapi raksasa media sosial seperti YouTube, Facebook, Twitter, dan Instagram? Apa yang menjadi motivasi keduanya?

Tujuan artikel ini adalah menjelaskan bagaimana blog seperti Kompasiana dan Indonesiana bersiasat menghadapi raksasa media sosial seperti YouTube, Facebook, Twitter, dan Instagram. Selanjutnya, peneliti juga menjelaskan kepentingan yang melatari praktik tersebut. Berikutnya adalah menunjukkan bahwa di tengah upaya dominasi (raksasa media sosial), kelompok subordinat (Kompasiana dan Indonesiana) akan terus berusaha mencari peluang agar bisa meraih manfaat.

Bersiasat berarti mencoba mengambil jalan tengah apa yang bisa dimanfaatkan dari raksasa media sosial. Bukan pula sepenuhnya mengalah lalu tak bisa berbuat apa-apa, melainkan berupaya menghadapinya dengan keterbatasan kemampuan yang dimiliki. Dalam pendekatan Gramscian soal hegemoni, situasi ini terkait dengan hegemoni tandingan. Hegemoni adalah penguasaan yang dilakukan melalui persetujuan dari kelompok yang tengah dikuasai (Simon, 2004; Fakih, 1996; Storey, 2003). Pada praktiknya, hegemoni akan dibayangbayangi oleh hegemoni tandingan yang 
muncul dari kelompok yang tengah dikuasai sebagai bentuk ketidakpuasan atas kinerja kelompok dominan. Hegemoni berjalan tidak pernah tuntas sehingga siasat dapat dibaca sebagai reaksi atas upaya dominasi kelompok dominan. Bentuknya tidaklah menolak secara keras keberadaan kelompokdominan, melainkan mengambil jalan tengah. Dalam konteks ini, Kompasiana dan Indonesiana dalam posisi aktif, tidak pasif dalam menerima upaya dominasi raksasa media sosial di arena informasi.

Kompasiana merupakan bagian dari kelompok Kompas Gramedia (KG) yang juga mengelola Harian Kompas, Kompas.com, dan Kompas TV. Indonesiana berada dalam Tempo.co yang merupakan bagian dari kelompok usaha Tempo. Kelompok ini juga mengelola Majalah Tempo, Tempo TV, dan Koran Tempo. Kompasiana sebelum akhirnya didapuk secara resmi berada dalam induk usaha Kompas.com pada 22 Oktober 2008, awalnya merupakan blog yang disediakan khusus untuk wartawan dan karyawan Kompas Gramedia ("Tentang Kompasiana”, n.d.). Sebagai blog yang sifatnya masih eksklusif, Kompasiana pertama kali muncul pada Mei 2008. Nama Kompasiana identik dengan P.K. Ojong, salah satu pendiri Kompas. P.K. Ojong mengelola Kompasiana pada kisaran 1960-1970 bergaya blog yang cair mengalir, tak kaku. Kompasiana mengelola konten-konten yang berasal dari warga berupa teks, foto, dan video. Konten yang diolah adalah konten-konten yang terkait reportase warga, opini, dan juga sastra.

Sementara itu, Indonesiana mulai dikenalkan ke publik pada 2013 di bawah pengelolaan Tempo.co, media daring yang menjadi bagian dari usaha Kelompok Tempo Media. Indonesiana merupakan blog yang ditujukan untuk warga yang ingin menyampaikan beragam konten, baik tulisan, foto, maupun video. Warga yang mengunggah bisa siapa saja asal mendaftarkan diri, serta mematuhi aturan konten yang telah digariskan. Fokus Indonesiana adalah tulisan-tulisan opini, bukan hasil reportase berbasis jurnalisme. Belakangan, demi kuantitas konten, tulisan-tulisan hasil reportase dari warga akhirnya diakomodir.

Riset-riset sebelumnya banyak mengangkat topik strategi pengelolaan media sosial yang dilakukan media arus utama. Seperti riset yang dilakukan Eddyono (2013) yang menunjukkan pola pemanfaatan media sosial, terutama Twitter, di TVOne, Kompas.com, dan Radio Trijaya. Selain itu juga riset yang dibuat oleh Paramastri dan Gumilar (2019) yang menunjukkan bagaimana Tirto.id berstrategi terhadap Twitter. Padahal, tak hanya media arus utama saja yang memanfaatkan media sosial, namun media sosial itu sendiri. Seperti yang disinggung sebelumnya, Kompasiana dan Indonesiana adalah berplatform media sosial sehingga menarik mengamati bagaimana media sosial berskala kecil (Kompasiana dan Indonesiana) bersiasat menghadapi raksasa media sosial seperti yang dikelola oleh Google dan Facebook. Sekaligus, mengamati kepentingan apa yang melatarinya (hal ini juga tidak ditunjukkan dengan jelas dalam riset-riset yang telah saya sebut sebelumnya).

\section{Metode}

Penelitian ini adalah penelitian kualitatif. Untuk menjawab pertanyaan penelitian, peneliti menggunakan datadata kualitatif yang diperoleh melalui wawancara, observasi, dan pengumpulan dokumen. Wawancara dilakukan atas sejumlah informan yang tidak ditetapkan jumlahnya, namun berdasarkan 
urgensinya terkait topik penelitian yang utamanya adalah pengelola Kompasiana dan Indonesiana. Selanjutnya, observasi dilakukan dengan mengamati aktivitas Kompasiana dan Indonesiana di ranah daring maupun luring, sekaligus mengamati media sosial yang mereka kelola. Berikutnya, penelurusan dokumen meliputi data traffic dan bukti-bukti yang mengarah kepada keuntungan yang diraih keduanya. Data-data yang terkumpul dikategorikan, dianalisis dan selanjutnya diambil kesimpulan. Pengambilan data telah dilakukan sejak 2017 hingga awal 2019.

\section{Hasil dan Pembahasan}

Sebagai media sosial berskala kecil (jika dibandingkan dengan keberadaan YouTube, Facebook, Twitter ataupun Instagram), Kompasiana dan Indonesiana mengikuti tren memanfaatkan raksasa media sosial seperti halnya yang dilakukan media arus utama saudara sekandungnya. Peneliti mendapati empat model pemanfaatan raksasa media sosial yang dilakukan Kompasiana dan Indonesiana, yakni: (1) memanfaatkan raksasa media sosial untuk untuk menyebarluaskan konten yang dihasilkan, termasuk promosi atau kampanye kegiatan; (2) menggunakan media sosial untuk meningkatkan kedekatan dengan anggota (pemilik akun) dan publik secara umum; (3) media sosial dimanfaatkan untuk mengatasi keterbatasan teknologi (menjawab tren video blog); dan (4) media sosial digunakan memantau isu yang tengah tren untuk menentukan arah kebijakan konten. Keempat model tersebut dijabarkan di bawah ini.

\section{Menyebarluaskan Konten dan Promosi}

Kompasiana dan Indonesiana, memanfaatkan media sosial untuk menyebarluaskan konten yang dihasilkan, termasuk promosi atau kampanye kegiatan. Konten yang dihasilkan seperti yang telah disebutkan sebelumnya, berupa jurnalisme warga (reportase warga) dan opini (termasuk sastra). Konten jurnalisme warga adalah konten yang berisi informasi yang berasal dari warga di mana cara penggalian dan penyampaiannya mengikuti kaidahkaidah jurnalistik yang telah diadaptasi (lihat Eddyono, Faruk, \& Irawanto, 2019a; 2019b). Kompasiana dan Indonesiana memiliki akun di berbagai media sosial. Kompasiana memiliki akun di Twitter, Instagram, Facebook dan YouTube. Begitu pula dengan Indonesiana. Meskipun demikian, jumlah pengikut setiap media sosial lebih banyak dimiliki oleh Kompasiana dari pada Indonesiana. di Facebook saja jumlah pengikut Kompasiana lebih dari satu juta, sementara Indonesiana diikuti 17 ribuan pengikut. Ini disebabkan "amunisi" yang dimiliki Indonesiana dalam mengelola media sosial lebih terbatas di banding Kompasiana. Perlu diketahui, Kompasiana telah diposisikan sebagai media yang harus mendapatkan untung dan telah dijadikan sebagai unit bisnis dalam Kelompok Kompas Gramedia. Berbeda dengan Indonesiana yang masih berada dalam pengelolaan Tempo.co dengan jumlah tim konten yang terbatas. Kebijakan tersebut akan menentukan banyak tidaknya tim yang dilibatkan serta modal yang disediakan untuk pengembangan. 
Ibarat lapak di pasar-pasar atau etalase di toko-toko di mana produk yang dijual dipampang dengan menarik, media sosial adalah tempat yang digunakan memamerkan konten dan promosi. Tujuannya adalah agar konten yang dihasilkan bisa diketahui oleh warganet lalu mengklik tautan dan membaca isinya, dan kalaupun bisa ikut di-share sehingga menjadi lebih viral. Upaya ini untuk meningkatkan traffic keterbacaan yang bisa diakumulasi demi mencari sponsor.

Traffic merupakan total aktivitas khalayak di media daring ketika mengakses media tersebut. Elemennya berupa: visit, unique visitor, pageview, dan length of visit (Margianto dan Syaefullah, 2012). Visit bisa dianggap seberapa banyak khalayak dalam mengunjungi sebuah situs pada 30 menit pertama. Unique visitor merupakan kunjungan perangkat komputer dengan alamat IP dan browser yang sama dalam sebulan. Sementara itu, pageview merupakan banyaknya jumlah halaman yang dilihat. Lalu, length of visit menunjukkan lama atau tidaknya orang bertahan mengunjungi sebuah situs. Angka traffic itu bisa dilihat atau didapat dari mesin traffic yang dilanggan, salah satunya adalah Google Analytic.
Kedua media memiliki cara yang hampir mirip dalam menempatkan konten di media sosial. Twitter dikhususkan untuk menempatkan konten-konten terbaru dan dipilih secara khusus oleh pengelola konten (lihat gambar 1), Instagram dikhususkan menampilkan foto dan video pendek aktivitas yang tengah dilakukan, YouTube dikhususkan untuk menampilkan video kegiatan berdurasi panjang, sedangkan Facebook kombinasi di antara semuanya.

Dalam pantauan peneliti terhadap media sosial yang digunakan oleh keduanya, konten-konten pilihan ataupun terpopuler sering kali diviralkan di Facebook dan Twitter. Khusus di Instagram, yang sering kali ditampilkan adalah kegiatan-kegiatan yang sedang dijalani dalam bentuk foto, video, ataupun grafis. Pada YouTube juga demikian, yang ditampilkan adalah video dokumentasi kegiatan dan kampanye yang dilakukan keduanya. Terus meningkatnya pertumbuhan pengguna media sosial membuat kedua media harus memahami sekaligus masuk atau ikut serta dalam budaya media sosial. 


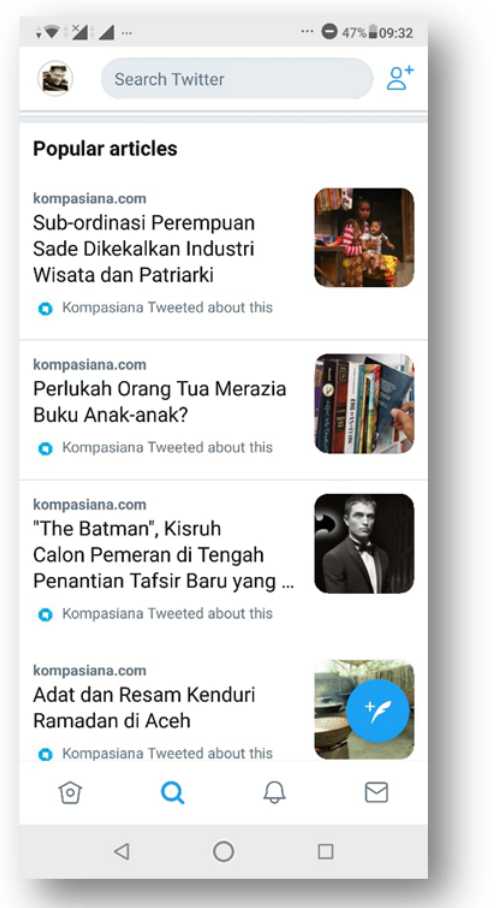

Gambar 1: Tampilan artikel terpopuler Kompasiana di Twitter. Judul artikel yang tampil di sini berasal dari artikel yang sudah dipilih dan dikurasi oleh pengelola konten lalu dipromosikan via Twitter. (sumber: Twitter).

\section{Mengintimkan Diri dengan Khalayak}

Kompasiana dan Indonesiana menggunakan media sosial untuk meningkatkan kedekatan dengan anggota (pemilik akun) dan publik secara umum. Pengelola berharap dengan kehadiran media sosial, interaksi dengan publik, terutama pemilik akun bisa lebih meningkat. Interaksi bisa berupa like, comment, dan share. Adanya akun media sosial juga memudahkan publik untuk memention dalam sebuah posting-an ataupun mengisi komentar langsung di laman media sosial. Upaya mendekatkan diri dengan publik, terutama pemilik akun, dengan menggunakan media sosial adalah hanya salah satu cara saja. Kompasiana dan Indonesiana sebenarnya memiliki beragam cara untuk ini, seperti mengadakan pelatihan-pelatihan, baik yang disponsori maupun tidak, dengan tema-tema khusus dan mengundang berbagai kalangan.
Status Syifa Annisa di Facebook pada 25 Februari 2019 yang me-mention Kompasiana merupakan contoh praktik untuk meraih kedekatan secara daring. Syifa membuat status soal plagiarisme. Statusnya itu direspon 17 emoticon dan tiga komentar (lihat gambar 2 pada bagian bawah). Contoh lainnya adalah status Rahmad Agus Koto di Facebook pada hari yang sama. Statusnya juga me-mention Kompasiana. Rahmad dalam statusnya mempertanyakan apakah akunnya di Kompasiana bisa dihapus. Status Rahmad mendapat 84 emoticon, satu kali dibagikan, dan empat komentar. Komentar, suka, dibagikan, atau hanya sekadar dilihat adalah hal penting dalam bermain media sosial karena bisa diakumulasikan untuk mencapai target tingkat kedekatan (lihat gambar 3).

Kedekatan akan berujung pada interaksi atau engagement dengan pengikut. Sebuah akun media sosial akan dianggap memiliki tingkat interaksi (engagement rate) yang tinggi jika 
pengikut secara produktif memberikan dukungannya untuk memberikan like, comment, dan share atas sebuah konten yang tampil di media sosial tertentu. Khusus di Instagram, cara menghitung tingkat interaksi, menurut Sociabuzz (n.d.), adalah dengan menjumlahkan jumlah keseluruhan likes dan comments dari sejumlah posting konten guna menemukan angka rata-rata total interaksi lalu dibagi dengan jumlah pengikut. Dalam tren bermedia sosial, tingkat interaksi ini bisa digunakan untuk mendapatkan untung. Tentunya jika dikelola dengan baik.

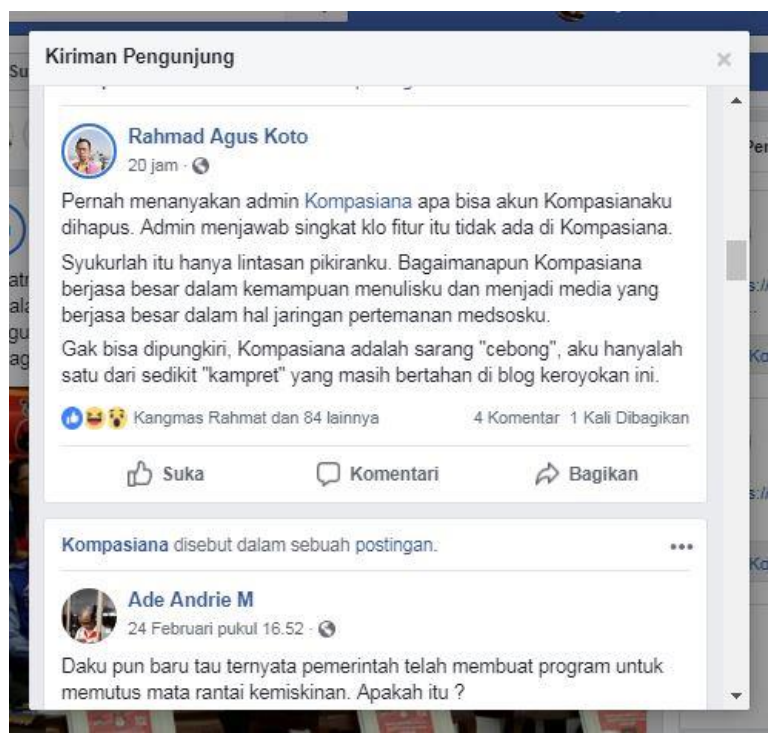

Praktik mention bisa pula dilihat sebagai bentuk "cari perhatian" agar bisa tampil secara otomatis di laman Facebook seseorang. Facebook memberikan fasilitas mention agar penggunanya leluasa memunculkan kontennya di halaman pemilik akun yang di-mention. Bagi pemilik akun yang di-mention bisa menghapus mention sehingga konten tersebut tidak muncul di feed-nya. Kompasiana dan Indonesiana tidak memilih cara menghapus mention itu karena dengan membiarkannya maka akan menguntungkan, menambah pengikut dan interaksi (kecuali jika konten yang tampil dianggap merugikan).

Gambar 2: Tampilan Status Kompasioner yang me-mention Kompasiana. Ini adalah contoh bentuk interaksi di media sosial. (sumber: Facebook).

\section{Mengatasi Keterbatasan Teknologi}

Media sosial dimanfaatkan untuk mengatasi keterbatasan teknologi. YouTube adalah media sosial di bawah pengelolaan Google yang khusus menampilkan video berkapasitas besar. Server yang dimiliki Google, termasuk untuk mengelola YouTube, tersebar di banyak negara, seperti Finlandia, Belgia, Amerika, dan negara-negara di Asia (Kristo, Agustus 25, 2015). Setidaknya, ada 100.00o server yang digunakan

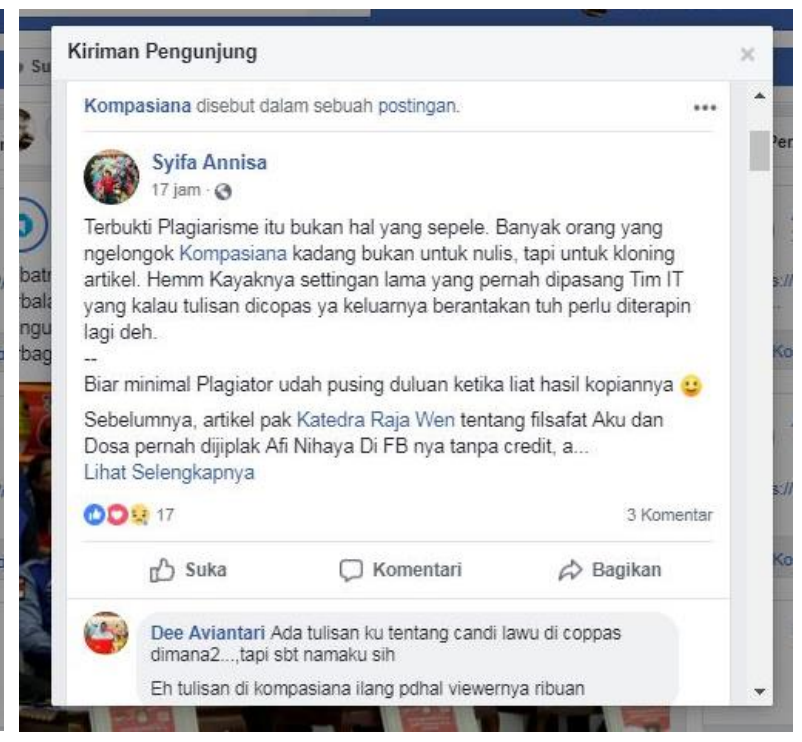

menjalankan aktivitas Google. Server tersebut bisa berkomunikasi langsung secara random dan terkoneksi satu sama lain dengan kecepatan sekitar 10 GB/detik. Jika dibandingkan dengan server Kompasiana dan Indonesiana tentu sangatlah jauh sehingga tak mungkin mengakomodir konten-konten video. Jika dipaksa, maka server akan down. YouTube pun dimanfaatkan. "Baru sebatas embed dari YouTube begitu. Player-nya dari YouTube cuma embed di 
halaman Kompasiana," kata Nurulloh, COO Kompasiana (wawancara, 28 Juni 2018).

Kompasiana menilai bahwa konten video seperti vlog tengah menjadi tren saat ini. Sehingga pengelola harus memiliki strategi memanfaatkannya demi peningkatan traffic. "Nah dampaknya akan ada orang yang lebih senang ngevlog daripada nge-blog. Karena kalau mau nulis kan mikir dulu, ya. Kalo video tinggal ngomong dan edit-edit langsung tayang," jelas Iskandar Zulkarnaen, mantan COO Kompasiana (wawancara, 25 Oktober 2017).

Praktik meng-embed atau menempel URL pun dikembangkan lagi oleh Kompasiana. Pengelola menyiapkan kanal Video yang secara khusus menampilkan konten video dengan memanfaatkan YouTube (lihat gambar 3). Tentu saja, YouTube juga diuntungkan dengan cara ini karena videonya menjadi lebih masif, ditempel sana-sini. Upaya ini sebenarnya juga disadari oleh Indonesiana. Meskipun Indonesiana belum membuat kanal khusus video memanfaatkan YouTube, pengelola sangat rajin mempersuasi peserta di berbagai pelatihan, terutama yang ditujukan untuk anak muda, agar berani menampilkan video hasil karyanya di Indonesiana dengan cara meng-embed dari YouTube.

Mengembangkan konten video dengan memanfaatkan YouTube bukan berarti membuat Kompasiana akan mengarahkan bisnisnya menggarap konten video sepenuhnya. Ini adalah siasat dalam menjawab tren vlog ala YouTube yang tengah diminati. Posisi Kompasiana hingga kini masih tetap berfokus pada blog, setidaknya sampai peminat blog menurun drastis dan tak mungkin dimonetisasi lagi. Pengelola yakin bahwa tren blog masih menjanjikan. "Tapi kalo untuk tulisan (blog) akan tetep punya audience-nya sendiri karena dia lebih imajinatif, feel-nya juga lebih dapat, lebih enak untuk orang-orang yang memang untuk konteks literasi baca-tulis, tentu itu akan terus berkembang," kata Iskandar Zulkarnaen optimis.
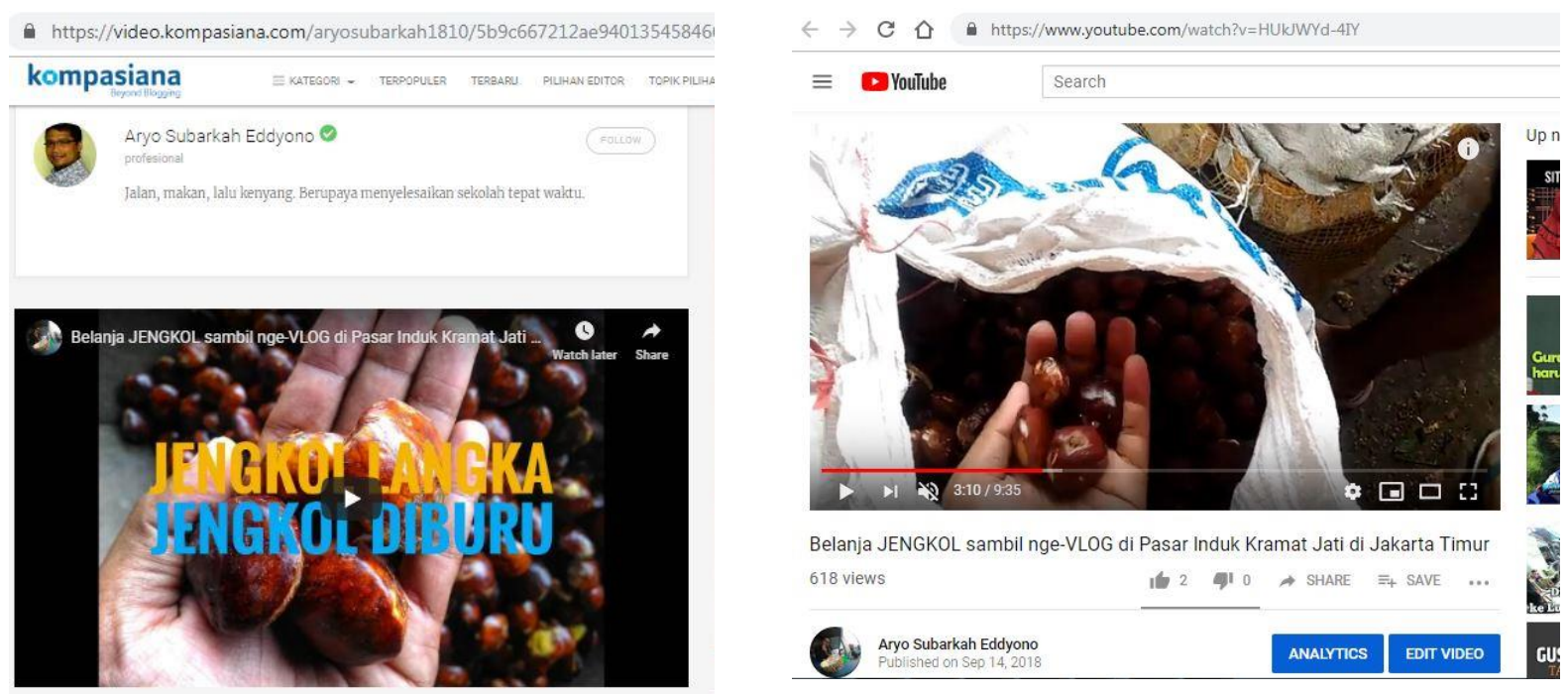

Gambar 3: Tampilan konten video yang pernah peneliti buat di kanal Video Kompasiana (atas) dengan meng-embed dari akun YouTube (bawah) (sumber: Kompasiana). 


\section{Memantau Tren Demi Konten Populer}

Kompasiana dan Indonesiana memanfaatkan media sosial untuk memantau isu yang tengah menjadi tren untuk menentukan arah kebijakan konten. Dalam menentukan isu yang akan dijadikan topik pilihan, Kompasiana tidak sembarangan memutuskannya. Harus ada alasan yang tepat dan masuk akal, serta berpotensi meningkatkan traffic keterbacaan untuk memilih isu dan kontennya. Salah satunya adalah dengan mencari tahu isu apa yang lagi tren di media sosial. Melalui perangkat lunak khusus atau sekadar memantau menu trending topic di berbagai media sosial, Kompasiana biasanya akan menemukan isu-isu hangat yang tengah dibicarakan warganet. Ketika isu telah ditemukan barulah diputuskan untuk disebarluaskan kepada Kompasianer (sebutan pemilik akun di Kompasiana). Salah satunya, Kompasiana memiliki program ProKontra yang berisi konten-konten pilihan yang isunya seputar perdebatan yang tengah viral. Upaya menjaring isu di media sosial ditujukan untuk menentukan topik-topik yang bisa diangkat di ProKontra.

Sementara di Indonesiana, cara ini digunakan untuk menempatkan kontenkonten di etalase laman utama karena berpeluang dibaca banyak orang. Jika saat itu ada isu tertentu yang lagi hangat dibicarakan di media sosial, maka admin akan memprioritaskan konten yang terkait isu tersebut dengan tetap mematuhi aturan konten. Konten-konten yang memenuhi standar ini akan dikategorikan dalam subkanal Viral.

Jika di media pers dominan berbasis daring, media sosial dijadikan aset karena jumlah pengikutnya yang berjumlah jutaan bisa diarahkan mendapatkan iklan, media sosial yang dikelola Kompasiana dan Indonesiana belum sampai ke posisi tersebut. Peneliti melihat apa yang dilakukan keduanya dalam hal membisniskan akun media sosial masih dalam taraf menjaring banyak pengikut, sekaligus coba-coba ikut tren. Keseriusan pengelola, kekayaan konten dan aktivitas, dan jumlah pengikut yang terbatas menyebabkan tampilan media sosial menjadi sekadarnya, terutama akun-akun yang dimiliki Indonesiana.

Pada 26 Februari 2019 dari pukul oo.oo WIB hingga pukul 10.48 WIB, akun Facebook Kompasiana telah mem-posting setidaknya tujuh status berisi konten yang tampil di Kompasiana. Sementara, Indonesiana belum mem-posting sama sekali. Posting-an terakhir adalah tanggal 22 Februari pukul 15.18 WIB, berkonten tentang perubahan iklim dan ajaran Lord Boden Powell, bapak Pramuka sedunia. Sementara itu di Twitter, akun Indonesiana terakhir mem-posting pada 8 Januari 2019 dengan konten cerita perjalanan panjang infrastruktur di pemerintahan Jokowi (pengamatan 26 Februari 2019). Akun Twitter Kompasiana masih lebih aktif. Pada pengamatan 26 Februari 2019 dari pukul oo.oo WIB hingga 11.00 WIB, akun ini telah menayangkan status sebanyak hampir 45 status. Di YouTube, melalui akunnya, Kompasiana menanyangkan 93 video sejak 4 tahun lalu hingga saat artikel ini ditulis (26 Februari 2019). Sementara Indonesiana telah menanyangkan 8 video sejak 3 tahun lalu. Begitu pula di Instagram, Kompasiana mendominasi jumlah posting-an dibandingkan Indonesiana. Indonesiana sadar atas kelemahan ini, sehingga konten-konten terbaik Indonesiana tak hanya diviralkan 
di media sosial yang dimiliki Indonesiana, tapi juga menggunakan media sosial Tempo.co. Facebook Tempo.co dengan nama akun @TempoMedia memiliki hampir dua juta pengikut.

Jadi, pada situasi ini, Kompasiana dan Indonesiana tidak sepenuhnya mengamini dominasi raksasa media sosial. Sebagai media sosial skala nasional berplatform blog, keduanya berupaya menyiasati dominasi tersebut dengan barbagai cara sesuai dengan kapasitas dan modal yang dimiliki. Bersiasat adalah pilihan baik yang bisa dilakukan keduanya agar bisa terus tumbuh dan menjalankan kepentingannya.

Sebelumnya, telah diketengahkan bagaimana Kompasiana dan Indonesiana bersiasat menghadapi raksasa media sosial. Ada empat model pemanfaatan media sosial oleh keduanya (lihat gambar 4). Pertama, media sosial digunakan untuk menyebarluaskan konten yang dihasilkan, termasuk promosi atau kampanye kegiatan. Kedua, Kompasiana
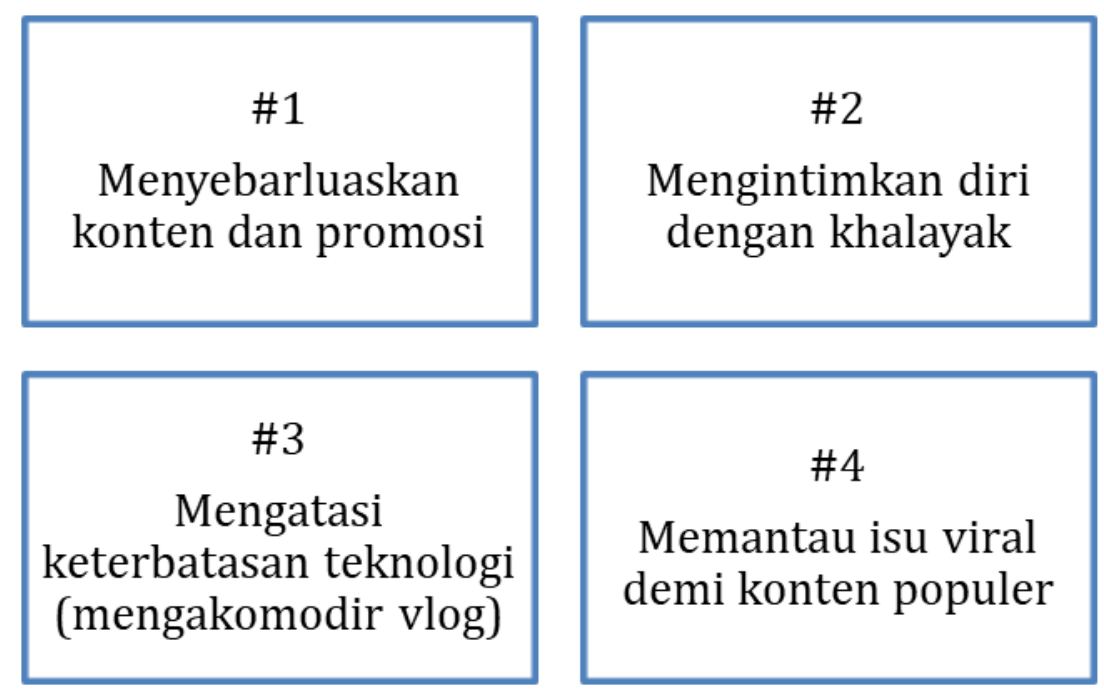

Gambar 4: Empat model pemanfaatan raksasa media sosial oleh Kompasiana dan Indonesiana. (Sumber: diolah dari data hasil penelitian) dan Indonesiana menggunakan media sosial untuk meningkatkan kedekatan dengan anggota (pemilik akun) dan publik secara umum. Ketiga, media sosial dimanfaatkan untuk mengatasi keterbatasan teknologi (menjawab tren video blog). Lalu, keempat, media sosial untuk memantau isu yang lagi tren untuk menentukan arah kebijakan konten. Meskipun keduanya memiliki pola yang sama dalam bersiasat menghadapi media sosial, namun pada dasarnya praktik yang dilakukan itu amat terkait dengan amunisi atau modal yang dimiliki. Kompasiana yang memiliki tim yang lebih banyak dalam mengelola konten warga, kapital

yang besar, dan teknologi yang lebih baik - jika dibandingkan dengan Indonesiana - lebih leluasa dalam memanfaatkan keberadaan raksasa media sosial. Sementara Indonesiana, berjalan dengan keterbatasan. Itulah mengapa geliat Indonesiana dalam membuat status terbaru di berbagai media sosialnya tidak semasif yang dilakukan Kompasiana. 
Pertanyaan berikutnya adalah apa motivasi Kompasiana dan Indonesiana memanfaatkan raksasa media sosial? Jawabannya adalah sebagai strategi meningkatkan traffic yang berujung pada upaya mengakumulasi kapital. Kapitalisme adalah model organisasi sosial ekonomi yang berfokus pada keuntungan. Di dalamnya, pengusaha dan lembaga bisnis (kapitalis) berupaya menyediakan kapital (yang menjadi salah satu cirinya) agar melalui kehadirannya praktik bisnis mampu menghasilkan barang dan jasa dengan imbal balik berupa laba dari produksi barang tersebut (Blackburn, 2013). Kapitalisme mensyaratkan kepemilikan individu dalam beragam alat produksi, ekonomi pasar, dan juga pembagian kerja agar mendorong pabrik berproduksi (Scruton, 2007). Marx (dalam Brewer, 1999) mengatakan bahwa kapitalisme memiliki dua wajah, yakni berupa sistem produksi komoditas, di mana barang-barang yang dihasilkan nantinya akan dijual, dan ia diproduksi karena kontrol kapitalis yang memperkerjakan buruh. Komoditas, dalah hal ini, bisa dipertukarkan karena memiliki nilai pakai dan nilai tukar. Nilai yang dikandung sebuah komoditas tergantung pada seberapa besar kerja sosial yang dibutuhkan untuk memproduksinya. Dengan kata lain, nilai komoditas akan tergantung pada biaya produksinya. Nilai tukar dan nilai pakai menjadi rawan jika terkait dengan buruh atau tenaga kerja yang dipakai dalam produksi (Johnson, 1994). Buruh berpotensi dieksploitasi dengan memperpanjang jam kerjanya namun dibayar dengan upah yang minim demi menghasilkan sebanyak-banyaknya komoditas untuk mendapatkan keuntungan. Buruh memang menjadi topik penting tatkala Marx menyinggung soal nilai pakai dan nilai tukar.
Lebih lanjut, saat mesin-mesin pabrik mulai mendominasi tenaga kerja manusia, maka sistem pabrik mengikuti pola mesin. Pekerja dianggap sebagai perangkat mesin yang harus patuh pada disiplin produksi mesin yang kaku dari pada membantu manusia dalam mempermudah pekerjaannya (Johnson, 1994). Kehadiran mesin selanjutnya akan membuat produksi semakin efisien. Persaingan antara para kapitalis pada akhirnya tak bisa dihindarkan dalam situasi masing-masing ingin mendapatkan keuntungan dengan cara apapun. Dampaknya adalah harga komoditas akan menjadi lebih murah. Meskipun demikian, dengan strategi sentralisasi dan konsentrasi modal, kapitalis akan tetap untung (Giddens, 2009).

Pada perkembangannya, komoditas tidak hanya bertumpu mesinmesin produksi dan buruh semata. Di ranah media, seiring kemajuan teknologi, kapitalis memiliki cara yang lebih beragam dalam mengakumulasikan laba. Smythe (1977) mengutarakan bahwa khalayak adalah pekerja bagi media (TV). Semakin bertambah khalayak menyaksikan tayangan itu, maka semakin banyak pula keuntungan yang diperoleh kapitalis media. Semakin tinggi angka penonton pada sebuah program, maka harga iklannya akan semakin melambung. Lalu, ketika iklan masuk atau tayang di media, maka itu adalah uang. Inilah yang disebut bahwa penonton menjadi komoditas bagi media. Pemikiran Smythe ini menjadi topik menarik yang terus dibicarakan para pemikir lainnya, ada yang mengoreksinya adapula yang menambahkannya. Meehan (1984) menambahkan bahwa selain khalayak, ada hal lain yang dikomodifikasikan, yakni rating atau pemeringkatan. Sementara Mosco (2009) menjelaskan ada tiga modus kapitalis dalam bisnis media, salah satunya adalah komodifikasi. 
Komodifikasi adalah proses mengubah nilai guna menjadi nilai tukar. Oleh kapitalis media, khalayak, isi (konten), dan tenaga kerja dikomodifikasi sedemikian rupa agar menjadi komoditas yang menghasilkan keuntungan atau nilai surplus.

Pemikiran soal komoditas media terus berkembang hingga saat ini. Di ranah internet, di mana pengguna adalah konsumen sekaligus produsen informasi, data pengguna berupa informasi apa saja yang diakses, diunduh, diunggah, jaringan sosial, minat, interaksi dengan pengguna lain, dan sebagainya dijual kepada pengiklan sebagai komoditas. Mosco (2009) menilai bahwa fenemona ini, seperti Facebook yang memanfaatkan informasi rinci penggunanya, merupakan penyempurnaan model komodifikasi khalayak yang sebelumnya pernah ia singgung. Dalam budaya media daring, traffic merupakan aspek utama yang menjadi komoditas guna mendapatkan keuntungan (Margianto dan Syaefullah, 2012).

Apa yang dilakukan Kompasiana dan Indonesiana ikut serta dalam tren media sosial dilatari kepentingan akumulasi kapital. Aktivitas di media sosial diarahkan untuk meningkatkan traffic, traffic lalu diarahkan untuk mendapatkan sponsor lalu berujung pada pendapatan. Media sosial menjadi salah satu pintu bagi kedua media menambah angka traffic. Bagi Kompasiana yang mandiri dalam mengelola bisnis, traffic diarahkan secara jelas untuk dijual kepada sponsor. Data-data traffic seperti jumlah pengunjung, seberapa lama pengunjung mengakses Kompasiana, dan interaksinya akan ditunjukkan kepada sponsor agar beriklan di Kompasiana (lihat gambar 5).
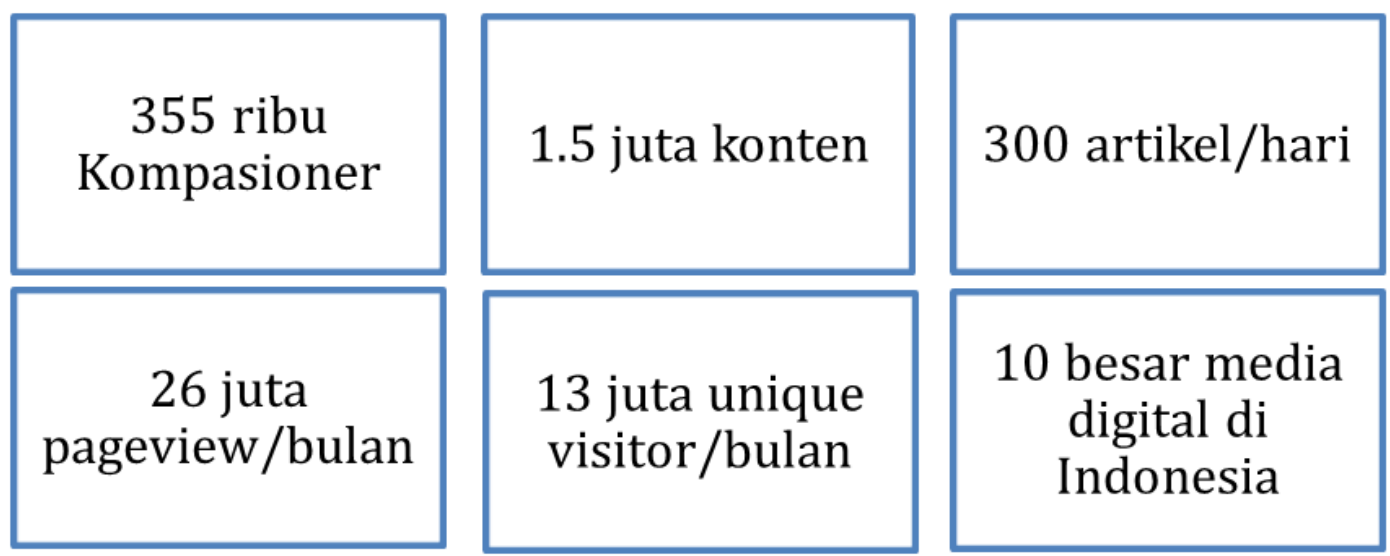

Gambar 5. Statistik Kompasiana per Desember 2017. (sumber: Kompasiana).

Setidaknya, ada dua model cari uang yang dilakukan oleh Kompasiana dengan memanfaatkan traffic yang ada. Pertama, adalah programmatic buying. Model ini adalah mendapatkan pendapatan secara pasif melalui salah satunya adalah Google Adsence. Berdasarkan perjanjian, agency seperti Google Adsence, akan menempatkan berbagai iklan di berbagai laman
Kompasiana di ruang-ruang kosong (banner) kanan, kiri, atas, ataupun bawah yang telah disediakan. Mengapa disebut pasif? V. Roro Sekar Wening, Mantan Manajer Sales Kompasiana (wawancara, 2 November 2017), mengatakan hal itu karena tidak membutuhkan kerja ekstra bagi tim marketing. Penempatan iklan dilakukan secara otomatis oleh agency. 
"Jadi yang penting kita setor posisi (ke) partner (agency). Lalu kemudian partner yang inject iklan-iklan kita, gitu. Tapi tentu saja, karena sambil merem (pasif), ya harganya tidak se-wow (mahal) dengan yang direct sell. Cuma serunya adalah, partner itu kan dari global (berbagai negara). Jadi (tidak perlu khawatir) iklan-iklan nya pun tidak jeruk makan jeruk (tidak dari dalam dalam negeri, sehingga tidak merugikan agency lokal), gitu Mas.” (V. Roro Sekar Wening, wawancara, 2 November 2017)

Kedua, adalah direct sales. Cara ini merupakan penjualan langsung dengan memanfaatkan tim marketing menjajakan beragam program ke klien. Misalnya saja mensponsori lomba blog, konten afiliasi, Kompasiana Nangkring, dan sebagainya. Tim marketing akan datang ke para klien dengan membawa portofolio Kompasiana berisi capaian traffic serta programprogram yang telah berhasil dilaksanakan. Roro Sekar Wening menyebut bahwa persentasi pendapatan yang diperoleh dari passive income adalah 8 persen, sisanya diperoleh dari direct sales sebanyak 91 persen.

Indonesiana memang tidak sekuat Kompasiana dalam mendongkrak dan memanfaatkan traffic. Faktor yang menyebabkannya, seperti yang penulis sebutkan di depan, adalah terbatasnya modal yang dimiliki untuk mengembangkan diri, termasuk tim yang terbatas dalam mengelola konten dan mencari sponsor. Alhasil, jumlah traffic yang masuk dari pengelolaan yang apa adanya itu hanya diarahkan untuk menambah traffic bagi media induknya. Tak ada angka pasti berapa jumlah traffic yang telah tercapai.

Berdasarkan pengamatan penulis di Indonesiana, bentuk iklan yang masuk dan tampil hanya berupa iklan digital.
Iklan seperti ini dianggap sebagai passive income dan tidak dikelola secara langsung oleh tim Indonesiana, melainkan tim marketing media induk. Iklan jenis ini adalah iklan yang akan menghasilkan uang jika pengunjung situs web melakukan klik pada tampilan iklan. Barulah pendapatan akan dihitung sejumlah seberapa banyak jumlah klik yang masuk. Besarannya tergantung pengiklan. Tim marketing tidak menjadikan Indonesiana prioritas untuk dijual karena traffic-nya tidak terlalu menjanjikan, sangat jauh di bawah kanalkanal prioritas untuk dipasarkan. Dalam Media Kit Tempo.co tahun 2018 edisi ke2, Indonesiana (saat masih berstatus sebagai kanal di Tempo.co) tidak muncul seperti halnya kanal-kanal yang memiliki traffic tinggi, seperti Halaman Depan, Nasional, Gaya Hidup, Metro, Ekonomi dan Bisnis, Internasional, Selebriti, dan Travel. Redaktur Indonesiana, Istiqomatul Hayati menjelaskan bahwa situasi ini terjadi karena pengelolaan Indonesiana belum maksimal (wawancara, 10 Februari 2018). Banyak kendala yang dihadapi. Selain kekurangan orang di lini redaksi guna mengelola konten, tim account executive (AE) juga enggan menjajakan Indonesiana ke pengiklan.

Oleh media induk dan pengelola yang sadar dengan situasi ini, Indonesiana tetap dipertahankan salah satunya adalah untuk membantu menjaga keberadaan komunitas bagi media induknya, sekaligus menjawab tren keterlibatan warga dalam produksi informasi. Dengan kata lain, Indonesiana belum difokuskan untuk berbisnis secara langsung seperti halnya pada Kompasiana. Kontribusinya adalah (masih) menjaga nama baik media yang menjadi induknya karena sebagai media pers ikut serta dalam tren mengelola konten warga, sekaligus diupayakan 
menambah traffic. Walaupun demikian, pengelola amat menyadari bahwa ada peluang pendapatan yang besar jika konten warga dikelola dengan baik.

Fenomena mengambil untung dari berbagai peluang yang ada merupakan ciri dari kapitalisme. Kapitalisme akan selalu berupaya mencari celah agar keuntungan bisa dicapai secara optimal (lihat Ritzer, 2002; Schumpeter, 2013; Kunio, 1990). Meskipun tak mampu menghadapi kekuatan raksasa media sosial, Kompasiana dan Indonesiana - sebagai bagian dari institusi bisnis media, bersiasat agar bisa memanfaatkan keberadaan raksasa media sosial mendapatkan traffic. Teknologi internet ternyata bisa mengakomodir upaya itu. Teknologi internet yang sarat akan kepentingan pasar (lihat McChesney, 2013) menyediakan ruang atau menjadi wahana bagi siapa saja untuk memanfaatkannya demi tujuan-tujuan tertentu, termasuk juga kepentingan pasar. Teknologi yang dimiliki raksasa media sosial memberikan kesempatan bagi upaya-upaya seperti yang dilakukan Kompasiana dan Indonesiana sejauh menguntungkan juga buat mereka. Bahkan, untuk tujuan-tujuan komersial, raksasa media sosial memberikan fasilitas khusus bagi pihak yang berminat (tentu saja dengan biaya yang sudah ditentukan). Fenomena ini seolah-oleh terlihat seperti saling membutuhkan, padahal sebenarnya penuh kepentingan untuk mendominasi.

\section{Penutup}

Temuan riset ini adalah Kompasiana dan Indonesiana tidak serta merta menjadi korban atas kehebatan raksasa media sosial (tidak pula pasif dalam mengahadapi raksasa media sosial). Keduanya berupaya mengambil jalan tengah atas upaya dominasi raksasa media sosial dalam arena informasi di dunia siber. Pengelola mengakui bahwa Kompasiana dan Indonesiana tidak akan mampu melawan keunggulan raksasa media sosial, yang bisa dilakukan hanyalah beradaptasi dan memanfaatkannya demi peningkatan traffic, setidaknya hingga saat ini. Kompasiana dan Indonesiana memanfaatkan raksasa media sosial untuk untuk menyebarluaskan konten yang dihasilkan, termasuk promosi atau kampanye kegiatan; menggunakannya untuk meningkatkan kedekatan dengan anggota (pemilik akun) dan publik secara umum.; dimanfaatkan untuk mengatasi keterbatasan teknologi (menjawab tren video blog); dan digunakan memantau isu yang tengah tren untuk menentukan arah kebijakan konten. Praktik ini dimotivasi kepentingan pasar. Pemanfaatan raksasa media sosial bermuara pada peningkatan traffic sehingga menarik di mata sponsor untuk beriklan. Upaya ini penting bagi Kompasiana dan Indonesiana untuk bisa bertahan dan mendapatkan keuntungan.

Artikel ini memang tidak sampai pada penjelasan dampak dari upaya Kompasiana dan Indonesiana memanfaatkan raksasa media sosial terhadap, misalnya, demokratisasi informasi ataupun kekuasaan dengan lebih mendalam sehingga menimbulkan ketimpangan-ketimpangan dalam masyarakat. Oleh karenanya, penelitian lebih lanjut bisa dilakukan untuk menguak hal itu (sekaligus mengkritisinya), terutama melihat ketimpangan-ketimpangan yang muncul karena praktik tersebut. Harapannya, penelitian mengenai media dalam memanfaatkan media sosial dan kaitannya dengan traffic dan pasar bisa lebih komprehensif. 


\section{Daftar Pustaka}

Annur, Cindy Mutia. (2019). Berkat Iklan, Pendapatan Facebook dan Twitter Naik di Kwartal I-2019. Katadata. Dilihat pada 28 Mei 2019 darihttps://katadata.co.id/berita/2 019/04/29/berkat-iklanpendapatan-Twitter-danFacebook-naik-di-kuartal-i-2019

Blackburn, Simon. (2013). Kamus Filsafat. Yogyakarta: Pustaka Pelajar

Bradley, Anthony J. (2010). A New Definition of Social Media. Gartner. Dilihat pada 17 Oktober 2019 dari https://blogs.gartner. com/anthony bradley/2010/01/o 7/a-new-definition-of-socialmedia/

Brewer, Anthony. (1999). Kajian Kritis Das Kapital Karl Marx. Yogyakarta: Teplok Press

Dayana, Anggit Setiani. (2019, 30 April). Google Alami Perlambatan Pertumbuhan Pendapatan di Bisnis Iklan. Tirto. Dilihat pada 28 Mei 2019 dari https://tirto.id/google-alamiperlambatan-pertumbuhanpendapatan-di-bisnis-iklan$\underline{\mathrm{dnnE}}$

Eddyono, Aryo Subarkah., Faruk., dan Irawanto, Budi. (2019a). Jurnalisme Warga: Liyan, Timpang, dan Diskriminatif. Jurnal Profetik 12 (1), hal. 6173. DOI: https://doi.org/ 10.14421/pjk.v12i1.1498
Eddyono, Aryo Subarkah., Faruk., dan Irawanto, Budi. (2019b). Menyoroti Jurnalisme Warga: Lintasan Sejarah, Konflik Kepentingan, dan Keterkaitannya dengan Jurnalisme Profesional. Jurnal Kajian Jurnalisme, 3 (1), hal. 117. Dilihat dari http:// jurnal.unpad.ac.id/kajianjurnalisme/article/view/21762

Eddyono, Aryo Subarkah. (2013). Twitter: Kawan sekaligus Lawan bagi Redaksi Berita. Journal Communication Spectrum. 3 (1), hal. $47-65$. Dilihat pada 26 Februari 2019 dari http://journal.bakrie.ac.id/inde x.php/Journal Communication spectrum/article/viewFile/766 $\lcm{617}$

Fakih, Mansour. (1996). Masyarakat Sipil untuk Transformasi Sosial: Pergolakan Ideologi di Dunia LSM Indonesia, Yogyakarta: Pustaka Pelajar

Giddens, Anthony. (2009). Kapitalisme dan Teori Sosial Modern. Jakarta: UI Press

Johnson, Doyle Paul. (1994). Teori Sosiologi Klasik dan Modern Jilid I. Jakarta: Gramedia

Katadata. (2018). Ini Media Sosial Paling Populer di Indonesia. Dilihat pada 26 Februari 2018 dari https://databoks.katadata.co.id /datapublish/2018/02/01/medi a-sosial-apa-yang-paling-seringdigunakan-masyarakatindonesia 
Kristo, Fino Yurio. (2015). Mengintip Kecanggihan "Otak" Raksasa Google. Detik.com. Dilihat pada 26 Februari 2019 dari https://inet.detik.com/cyberlife d-2999547/mengintipkecanggihan-otak-raksasagoogle

Kunio, Yoshihara. (1990). Kapitalisme Semu Asia Tenggara. Jakarta: $\mathrm{LP}_{3} \mathrm{ES}$

Margianto, JH. dan Syaefullah, A. (2012) Media Online: Antara Pembaca, Laba, dan Etika. Jakarta: Aliansi Jurnalis Independen (AJI) Indonesia Ford Foundation

McChesney, Robert W. (2013). Digital Disconnet: How Capitalism is Turning The Internet Against Democracy. New York London: The New Press

Meehan, Eileen. (1984). Ratings and the Institutional Approach: A Third Answer to the Commodity Question. Journal Critical Studies in Mass Communication, 1 (2), hal. 216225

Mosco, Vincent. (2008). The Political Economy of Communication. Sage Publishing

Newman, Nic. (2009). The Rise of Media Social and Impact on Mainstream Journalist. Reuters Institute for the Study of Journalism - University of Oxford
Nurlatifah, Mufti., dan Irwansyah. (2019). Fact-Checking Journalism sebagai Platform Kolaborasi Human and Machine pada Jurnalisme Digital. Jurnal Komunikasi, 13(2), hal. 121-134. Dilihat dari https:// journal.uii.ac.id/jurnalkomunikasi/article/view/13044

Paramastri, Nadia Araditya., dan Gumilar, Gumgum. (2019). Penggunaan Twitter sebagai Distribusi Berita dan News Gathering Oleh Tirto.id. Jurnal Kajian Jurnalisme, 3(1), hal. 18-38. Dilihat dari http://jurnal.unpad. ac.id/kajian-jurnalisme/article/ view/22450

Ritzer, George. Ketika Kapitalisme Berjingkrak. Yogyakarta: Pustaka Pelajar

Schumpeter, Joseph Capitalism, Democracy. Pustaka Pelajar

A. (2013). Socialism, Yogyakarta:

Scruton, Simon. (2007). Kamus Politik. Yogyakarta: Pustaka Pelajar

Smith, Noah. (2018). Social Media Looks Like the New Opiate of the Masses. Bloomberg. Dilihat pada 1 Juli 2019 dari https:// www.bloomberg.com/opinion/ articles/2018-04-04/socialmedia-use-bears-similarities-todrug-addiction

Simon, Roger. (2004). Gagaasangagasan Politik Gramsci. Yogyakarta: Pustaka Pelajar 
Smythe, Dallas W. (1977).

Communications: Blindspot of Western Marxism. Canadian Journal of Political and Social Theory. 1 (3), hal. 1-2

Sociabuzz. (n.d.). Instagram Engagement Rate Calculator. Dilihat pada 29 Mei 2019 dari https://sociabuzz.com/Instagra $\underline{m \text {-engagement-rate-calculator }}$

Storey, John. (2003). Teori Budaya dan Budaya Pop. Yogyakarta: Qalam

Tentang Kompasiana. (n.d.).

Kompasiana. Dilihat pada 5 Desember 2016 dari: http://www.Kompasiana.com/ tentang-Kompasiana
We Are Social - Hootsuite. (2018). The Digital in 2018: Internet Users Pass The 4 Billion Mark. Diakses pada 27 November 2018 dari https://wearesocial.com/blog/2 o18/01/global-digital-report$\underline{2018}$

We Are Social - Hootsuite. (2019). Digital in 2019. Diakses pada 26 Februari 2019 dari https://wearesocial.com/uk/dig ital-2019 